\title{
Improving the Efficiency of Chemotherapeutic Drugs by the Action on Neuroepithelial Tumors
}

\author{
Vladimir A. Kulchitsky et al. * \\ Institute of Physiology, National Academy of Sciences of Belarus, Minsk \\ Belarus
}

\section{Introduction}

The problem of cancer embraces a lot of unresolved issues, among which there dominates the problem of ascertainment of the mechanisms of uncontrolled growth and cellular spill of tumor neoplasm, composed of dividing cancer cells and cancer stem cells (Schatton \& Frank MH, 2009; Schatton et al., 2009; Frank NY et al., 2010). It is impossible to answer the question about a complete removal of the tumor tissue and simultaneous minimizing the adverse effects of surgical and other manipulations while removing the tumor without solving this problem. This is a particularly relevant goal for physicians who are engaged in treatment of brain tumors. The destruction of nerve tissue nonaffected by tumor growth has a negative impact on the integrative brain activity and at least on the central control of all bodily functions and homeostasis maintenance. How is it possible to reduce by-effects of major therapeutic technologies in neurooncology (surgical, radiological, chemotherapeutic), having preserved or enhanced their selective tumor damaging action?

Since you choose chemotherapy as one of the ways to impact on tumor tissue, it is impossible not to mention the commonly known toxic effect of chemotherapeutic agents on all body tissues. Destroying the tumor cells, cytotoxic agents kill healthy cells and tissues. Thus, local or systemic applying the chemotherapy leads inevitably to the destruction of healthy brain cells in case of the tumor localization within the cranial cavity and the spinal canal. Thus, one of the objectives of this work was to develop methodic of leveling the general toxic effects of chemotherapy while strengthening their local destructive effect on tumor tissue. What ways have been chosen to solve this problem?

Tumors of the brain and spinal cord have extremely variety (set) of histological forms which are accounted for their origin from the elements of various tissues and for peculiarity of

\footnotetext{
${ }^{*}$ Michael V. Talabaev², Alexander N. Chernov¹, Dmitry G. Grigoriev³, Yuri E. Demidchik4, Dmitry

G. Shcharbin', Nicholas M. Chekan', Vladimir V.Kazbanov' ${ }^{1}$, Tatiana A. Gurinovich ${ }^{1}$, Anatoly

I. Gordienko ${ }^{6}$, Elena K. Sergeeva ${ }^{6}$, Vladimir I. Potkin ${ }^{7}$ and Vladimir N. Kalunov ${ }^{1}$

${ }^{1}$ Institute of Physiology, National Academy of Sciences of Belarus, Minsk;Belarus

${ }^{2}$ Clinical Hospital of Emergency, Minsk;Belarus

${ }^{3}$ Belarusian State Medical University, Minsk;Belarus

${ }^{4}$ Belarusian Medical Academy of Post-Graduate Education, Minsk;Belarus

${ }^{5}$ Institute of Biophysics and Cell Engineering, National Academy of Sciences of Belarus, Minsk; Belarus

${ }^{6}$ Physical-Technical Institute, National Academy of Sciences of Belarus, Minsk; Belarus

'Institute of Physical Organic Chemistry, National Academy of Sciences of Belarus, Minsk, Belarus
} 
genesis not solved up to the end in respect to especially neuroepithelial tumors (Hirose \& Yoshida, 2006; Nicholas et al., 2011; Van den Eynde et al., 2011). The nervous system tumors account for almost $10 \%$ of all human neoplasms, and up to $20 \%$ for children (Alomar, 2010; Davis et al., 2010; Myung et al., 2010). Neoplasms of brain and spinal cord are the most common solid tumors in childhood. They take the second place in frequency after leukemia of all child malignancies. In childhood (under 14 years) the vast majority of cases occur in neuroepithelial tumors. Of these, about $80 \%$ are of six histological forms: medulloblastoma, juvenile pilocytic astrocytoma, diffuse astrocytoma, ependymoma, craniopharyngioma, and neuroblastoma.

Among the tumors of neuroepithelial tissues 9 sub-groups are selected out: astrocytic, oligodendroglial, ependymal, oligoastrocytic tumors (mixed gliomas), tumors of vascular plexus, and other neuroepithelial tumors (glial tumors of unspecified origin), neuronal and neuronal-glial, pineal, and embryonal tumors. In most cases glial tumors (gliomas) such as astrocytic, oligodendroglial, and ependymal glioma ones are detected. Histological diagnosis was based on identifying the predominant cell type.

Combined treatment of the brain cancer (children including), which supposes surgery interference together with chemo- and radiotherapy, does not so far reach the desired impact. According to statistics concerning only medulloblastoma, the average diseasefree and overall survival during 2-7 years for patients up to 4 years old is respectively $46 \%$ and $54 \%$. So, tiny comforting is aggravated by data that uniquely ascertain the growth of intracerebral cancer. Thus, in the U.S. during 30 years from 1973 to 2003 it increased from 4.1 to 5.2 for women and from 5.9 to 7.0 for men per 100000 population (Alomar, 2010). Similar dynamics were recorded by The Child Cancer Registry of the Belarusian Republic. The percentage of brain tumors rose from 2.5 to 3.3 per 100000 children living in Belarus from 1989 to 2005.

A number of intractable causes is due to a low curability of brain tumors. The most productive radical method of removal of cancer neoplasm is often limited by the fact of their location near vital centers. Courses of medical and radiation treatment in accordance with approved protocols HIT 91, PO/02-PO/04 (Dunkel et al., 2010; Rosenfeld et al., 2010) along with known positive ones embrace recognizable negative aspects. To the negative ones there pertain as follows: i) a low permeability of the blood-brain barrier being created by tight contacts of micro vessel intracerebral network, which became completed with a set of proteins (Claudine 1,5, Occludin and others), which are impermeable to hydrophilic low soluble compounds exceeding a diameter of $18 \AA$ and a molecular weight of $180 \mathrm{Da}$. The vast majority of cytotoxic drugs pertain to them (Erdlenbruch et al., 2000; Kemper et al., 2004; Xie et al., 2005); ii) a weak selectivity of the concentration of cytostatic in the place of neoplasm (Cragnolini \& Friedman, 2008); iii) an insufficiently studied mechanism of the action of traditional and new pharmacological agents, as well as their clearance, which hinders a reasonable estimation of the amount of molecules that come in direct contact with tumor cells (Gerstner \& Fine, 2007; Ta et al., 2009); iv) a lack of unified schemes of medical product application, taking into account the morphological structure of complex heterogeneous neoplasias, stages of their malignancy, and individual sensitivity of the tumor cells to them and patient age (Alomar, 2010; Myung, et al., 2010); v) a symptomatic toxic side effect, reduced to a violation of general tissue metabolism and endocrine function, to immunity suppression, involvement in a destructive reaction of abnormal elements along with intact (healthy) cell ones, as well as the development of complications (acute arachnoiditis, meningo encephalopathy, renal failure, passing 
deviation from the motor areas, speech, vision, hearing, stop of growth, and cognitive deficits with reduced intelligence), what in totality leads to disability (Kemper et al., 2004; Vega et al., 2003); vi) a limited range of available medications.

The postulates set forward underline the actuality of further improving of existing strategies and creating new ones for earlier diagnosis, prognosis and a more successful fight against cancer. One of the ways to the aim is a broad involvement in oncology of a very representative class of multifunctional endogenous biological regulators of peptide nature, generally called as growth factors. In own structure they number a series of families, among which are neurotrophins (Nerve Growth Factor (NGF), Brain-Derived Neurotrophic Factor (BDNF), Neurotrophins 3, 4, 5 (NT), Transforming Growth Factor (TGF), Fibroblast Growth Factor (FGF), Epidermal Growth Factor (EGF), Vascular Endothelial Growth Factor (VEGF), Insulin-Like Growth factor (IGF), and others, rating more than 50 different variants (Antonelli et al., 2007; Beebe et al., 2003). The key role belongs to growth factors in the capacity of epigenetic "directive" signals in the control of such fundamental morphogenetic processes in ontogenesis as growth, survival, proliferation, differentiation (i.e., the selection of the terminal tract of specialization by stem and progenitor cells), guided migration and elongation processes, synaptogenesis, regulation of cell homeostasis by apoptosis, regeneration, as well as maintaining a normal cyto-biochemical status of mature cells and their resistance to damaging factors (Alam et al., 2010; Charles et al., 2011; Vinores \& PerezPolo, 1983; Xie et al., 2005).

The interest to determine the significance of these compounds in tumor formation and in their reverse transforming potential has just relatively recently emerged, when it became vivid that virtually all types of neoplasias are synthesized not only by growth factors but actively expressize their receptors (Antonelli et al., 2007; Barnes et al., 2009; Blum \& Konnerth, 2005; Brossard et al., 2009; Evangelopoulos et al, 2004; Krúttgen et al., 2006; Nakagawara, 2001). At the same time we point out a startling fact: NGF was purified for the first time from sarcoma secretions S180, and protooncogenes sites, which take it, were purified from high-affinity TrkA and low relational P75 from biopsies of colon carcinoma (intestinum crassum) and human melanoma. It is much more interesting that bio testing of growth factors on its activity is performed on rat pheochromocytoma PC12 (Krúttgen et al., 2006).

The experiments proved that in vitro the cell lines of neuroblastoma (IMR-32, SY-5Y, SK-N$\mathrm{SH}, \mathrm{NB}-\mathrm{GR}$ ) and medullary pheochromocytoma cease to divide in the presence of NGF and are transformed into neuron-like elements at braking formation of DNA, at the intensification of including labeled amino acids, at the appearance of sprouts, at the growth of size, substrate adhesion together with the formation of pseudoganglies and at the occurrence in membrane of electrical excitability (Krúttgen et al., 2006; Poluha et al., 1995). On the other hand, the ability of NGF in vivo to reduce the number of induced nitrosourea by neurinomas was revealed, as well as the speed of their development, and the ability to reduce the volume and to prolong animal survival after subcutaneous injection or intracerebral implantation of anaplastic glioma cell F98, T9, and neurinomas (Yaeger et al., 1992). The predictive value of identification of perceiving Neurotrophins receptors is overviewed. So thus the over expression of TrkA and C (for NT-3) in neuro-, medulla and glioblastomas promises a favorable outcome, due to a spontaneous regression (through differentiation), the inclusion of suicide programs or autophagy (Blum \& Konnerth, 2005; Collins, 2004; Krúttgen et al., 2006; Yamaguchi et al., 2007). Patients with low or no detectable levels of these receptors in medulloblastoma exhibit 5-fold risk of death than with 
a high level (Krúttgen et al., 2006). Per contra, the enhanced expression of TrkB (ligand $\mathrm{BDNF})$, which takes place in aggressive tumors, where isoforms often truncated and lacked of intracellular domain, goes with the pessimistic ending.

In this light the aim of the research was to study individual and combined effects of some of cytostatic and growth factors (Liu et al., 2010), which are in circulation, on the survival of primary culture of cells. Alongside an attempt of the combined action of cytostatic, that is the factor of Nerve Growth and Dendrimers (or Heterocyclic Compounds) on primary culture cells of neuroepithelial tumors was undertaken. Dendrimers are the extended threedimensional molecules which contain a large number of active functional groups on the outer surface (Morgan et al., 2006; Waite \& Roth, 2009). We focused on one of the most common types of Dendrimers - Polyamidoamine, (PAMAM), containing ethylenediamine core and branching of methyl acrylate and ethylenediamine (Kang et al., 2010). We aimed at verifying the hypothesis about the possibility of dose reducing of cytostatic at combined application of chemotherapy with growth factors and nanoparticles, in particular Dendrimers in these experiments. The fifth generation of Dendrimer (PAMAM G5) was used. The effect of combinations of cytostatic, Nerve Growth Factor and Dendrimers or the cytostatic agent, Nerve Growth Factor and Heterocyclic Compounds was studied in separate series of experiments. Heterocycles of isoxazole series (Isoxazole) and isothiazolyl (Isothiazole) (typical representatives of 1,2-azoles) are structural fragments of a wide range molecules of active physiologically substances, what causes a growing interest in the research of the synthesis and in the study of the biological properties of these compounds. Isoxazole heterocycle is a compound part of molecules of the cytotoxic, antitubercular agents, anticonvulsants, and pesticides.

The compounds to be perspective for the treatment of Alzheimer's disease and inflammatory, antithrombosis and anticonvulsive drugs were identified among the derivatives of isothiazolyl. It was recently found that some isothiazolyls were inhibitors of kinases and could be used in the treatment of tumors. For example, isothiazolyl with urea function in position 3 is an inhibitor of tyrosine kinases and now it is under studying as an anticancer drug CP-547, 632 (Beebe et al., 2003). The fellow-colleagues of Institute of Physical Organic Chemistry NAS of Belarus developed methods for the synthesis of new 5substituted 1,2-thiazol-3-ilcarbamids and their heteroanalogs - 1,2-oxazole-3-ilcarbamids isosteres known as inhibitors of tyrosine kinases, which are of some interest for testing in our planned experiments. The goal of these experiments was to find ways of reducing the dose of cytotoxic drugs, under condition of preserving or increasing the toxic effects of chemotherapy on tumor tissue.

\section{Methodic}

The biopsy material was taken from 67 children aged from 1 to 15 years old who were treated at the children's neurosurgical department of Municipal Clinical Emergency Hospital in Minsk from November 2008 to December 2010.

\subsection{The research protocol}

The biopsy material taken during the fine-needle stereotactic or neurosurgical operation was transported in an hour to the Pathology Laboratory to determine the histology forms of the tumor and degrees of its malignancy, and was simultaneously delivered to the Laboratory 
of Cell Monitoring to assess individual sensitivity of tumor cells to chemotherapeutic drugs in vitro. After the mentioned period $0.5 \mathrm{ml}$ of chemotherapy was added in doses approved by instructions and converted either to a square cup $\left(10.0 \mathrm{~cm}^{2}\right)$ or to $\beta$-subunit of recombinant human NGF (Sigma-Aldrich, USA, $1.0 \mu \mathrm{g} / \mathrm{ml}$ ) or to Dendrimers (PAMAM 0.1, 1.0, $10.0 \mu \mathrm{g} / \mathrm{ml}$, Sigma-Aldrich, USA), or to heterocyclic compounds $(0.1,1.0,10.0 \mu \mathrm{g} /$ $\mathrm{ml}$ ), or to these or others in various combinations. Each series of observations in vitro consisted of 30 applications $(n=30)$. Assessment of the viability of tumor cells was estimated in 24 hours after putting test compounds into the environment for their ability to incorporate trypan blue. For this matter the cell suspension was mixed with $2 \%$ dye solution in saline buffer $\mathrm{pH}=7.2$ at a ratio of 1:10 and transferred into Goryaev's chamber, where the number of dead (paint over) and living (light) elements was counted at a percentage. The obtained data were reported to neurosurgeons who together with other specialists developed the tactics of post-operative treatment and determined prognosis.

\subsection{Cytoscopic study}

Cytoscopic study of surgical specimens was carried out after using the methods of frozen sections, or the crushed drop. The final conclusion of the histological form of the tumor and its malignancy degree was made after alcohol treatment, filling material in paraffin, sectioning and staining by the following methodic: a method of staining with hematoxylin and eosin; histochemical methods for the detection of glial filaments, collagen and reticulin fibers; immunohistochemical studies for detection of acidic glial fibrillary protein, neurofilaments, synaptophysin, and neuron-specific enolase; a definition of PCNA, Ki-67, cyclins in order to clarify the nature of proliferative activity. The conducted cytoscopic research allowed to identify indications of malignancy and was a guide to neurosurgeons in case of choosing the treatment tactics.

\subsection{Cultural studies}

Pieces of biopsy material were washed from the blood and mechanically comminuted in Hank's solution (Sigma-Aldrich, USA) with Gentamicin sulfate added, and then for $30 \mathrm{~min}$ they were put in a mixture of $0.25 \%$ trypsin solution in Ethylenediaminetetraacetic acid (EDTA) $(2 \mathrm{ml})$ at a ratio of 1:3. The effect of the enzyme was inhibited by adding $3 \mathrm{ml}$ Fetal Calf Serum - FCS (Sigma-Aldrich, USA) for a period of 3-5 minutes. The material treated in such a way was crushed under a microscope with a sterile blade up to pasty consistency and then was taken to a sterile Petri dish with medium Dulbecco's Modified Eagle's Medium (DMEM) (Sigma-Aldrich, USA), with adding ETS at a ratio of $1: 10$ and $4 \%$ sulfate solution Gentamicin $\left(10^{-4} \mathrm{~g} / \mathrm{l}\right)$. The cells obtained from the substrate were grown in a medium of this composition for $2-7$ days at $37^{\circ} \mathrm{C}, 95 \%$ humidity and $5 \%$ partial pressure of $\mathrm{CO}_{2}$ (Chekan et al., 2009). Stay duration of the cells in vitro was dictated by the speed of the attachment to the substrate.

\subsection{Clinical, laboratory and instrumental methods}

Clinical, laboratory and instrumental methods of the study included a list of routine clinical examination methods and laboratory diagnostics, as well as computed tomography and nuclear magnetic resonance. The credibility of differences between the average values was set by a Mann-Whitney test for nonparametric samples using the computer program StatPlus 2005. Differences were estimated to be significant at $P<0.05$. 


\section{Results}

The following types of cancer were included according to the histological conclusions based on classification of brain tumors (WHO, 2007) into the observations: astrocytic, embryonic, and compiled under the title "other types" of neoplasm. In the group of cancers of astrocytic origin were present: pilocytic, pilomixoidnic, protoplasmic, pleomorphic, anaplastic neoplasm. Medulloblastoma, atypical teratoidnic/rabdoidnic tumor of posterior fossa, and malignant neuroectodermal tumor of the left temporal lobe were in the category of embryonic tumors. The category of "the other options" of neoplasm included: anaplastic oligodendrogliomas, oligoastrocytomas of a cerebellar vermis, ependymoma, gangliogliomas of a mixed neuroglial type, immature teratoma of a pineal region, which was attributable to germinocell tumors, glioma of an optic chiasm, and a gemangioblastoma to be regarded as an intramedullary tumor of a cervical spinal cord.

It was revealed in the experiments in vitro that Cisplatin (Merck, USA, $1.0 \mu \mathrm{g} / \mathrm{ml}$ ) took priority in the samples of pilocytic astrocytoma, medulloblastoma, and malignant neuroectodermal tumors of the temporal lobe, where the percentage of dead cells reached respectively $61.9 \pm 12.9,40.9 \pm 11.4,41.6 \pm 8.5,68.6 \pm 7.8$ reliably exceeding the one in those experiments where the cells of a primary culture of neuroepithelial tissue devolved out of contact with chemotherapy $(14.3 \pm 5.0 \%)$. A similar position was taken by Carboplatin (Merck, USA, $4.0 \mu \mathrm{g} / \mathrm{ml}$ ) in biopsies from pleyomorfic xanthoastrocytoma, anaplastic oligodendroglioma (Fig. 1), optic chiasm glioma and atypical teratoid / rhabdoid tumors (Fig. 2) with lethality according to the order of enumeration $57.9 \pm 5.9,68.4 \pm 10.6,78.9 \pm 4.1$ and $79.5 \pm 1.0 \%$.

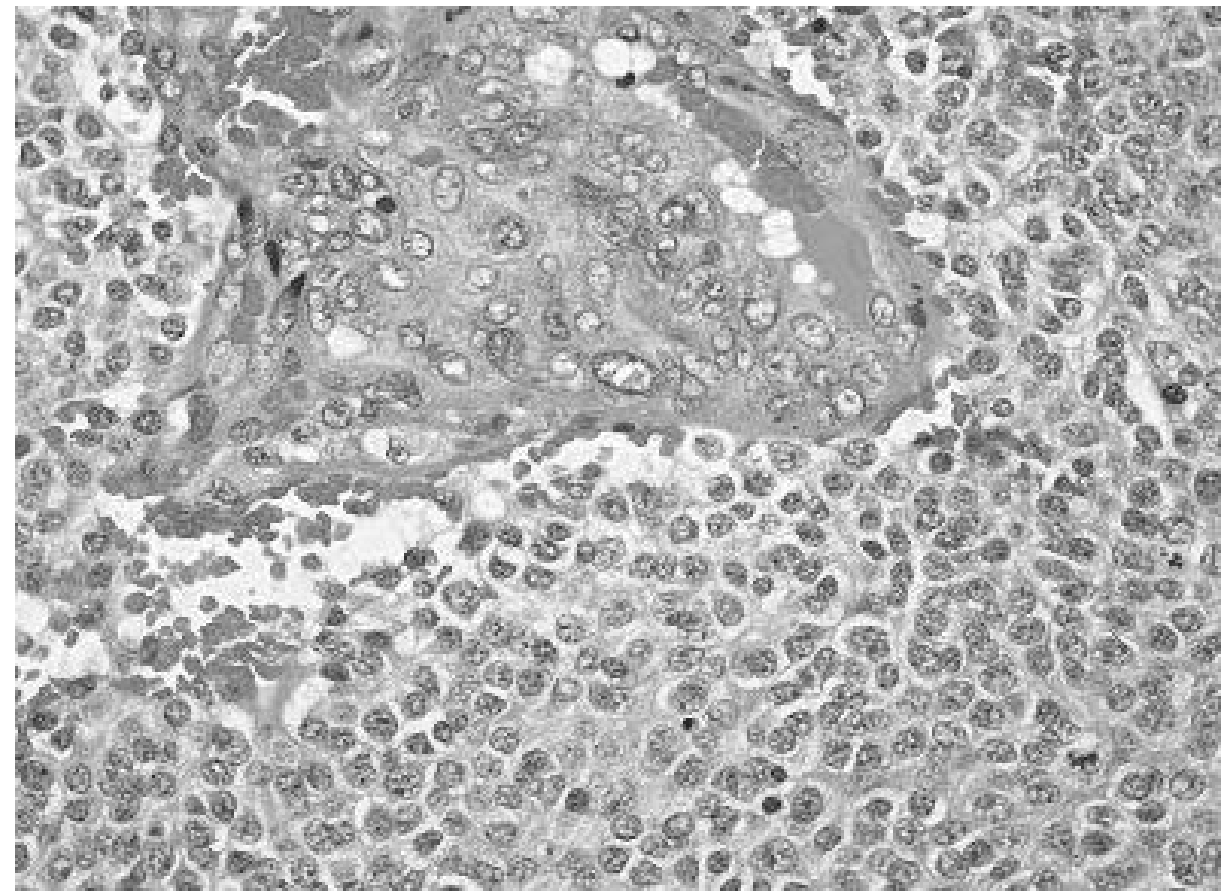

Fig. 1. Anaplastic oligodendroglioma 


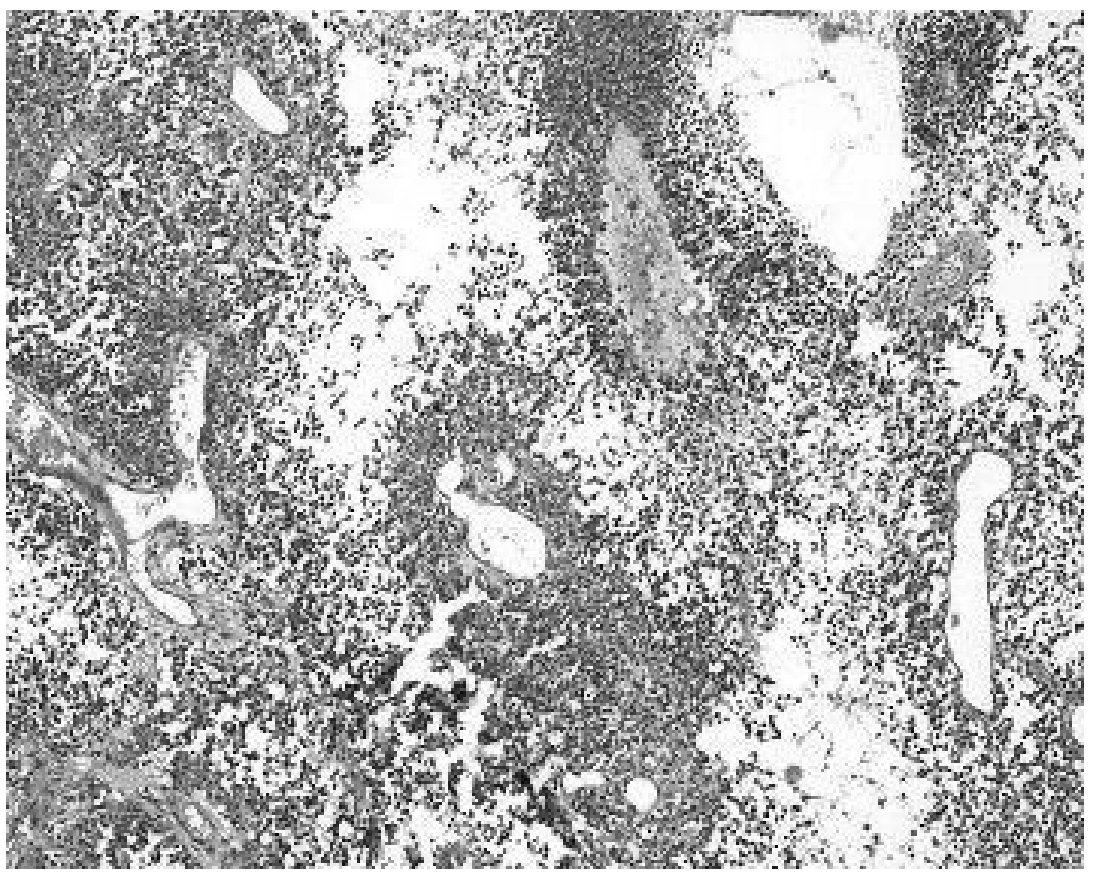

Fig. 2. Atypical teratoid / rhabdoid tumor

The same can be said about Etoposide (Ebewe Artsnaym., Austria, $1.0 \mu \mathrm{g} / \mathrm{ml}$ ) in relation to the protoplasmic astrocytoma cells $(61.0 \pm 4.7 \%)$, oligoastrocytoma $(55.1 \pm 8.5 \%)$ (Fig. $3 \mathrm{a}, \mathrm{b})$ and especially about hemangioblastoma $(74.7 \pm 3.9 \%)$.

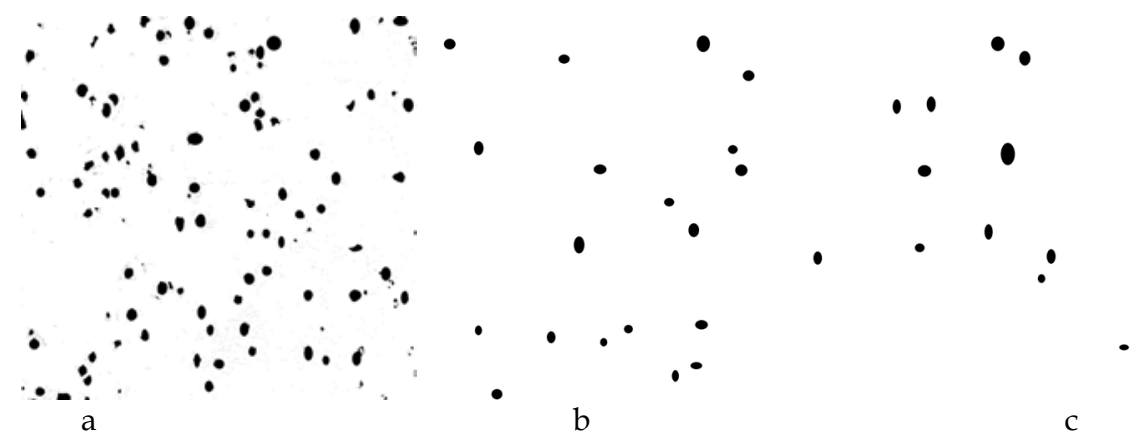

Fig. 3. Oligoastrocytoma cell survival in a day after the application of Etoposide (b) and $\beta$ NGF (c) in comparison with intact cells of primary culture of the tumor (a). The magnification is $\times 312.5$.

Cytarabine (Belmedpreparaty, Belarus, $1.0 \mu \mathrm{g} / \mathrm{ml}$ ) effectively suppressed the cell vitality in cultures of anaplastic astrocytoma $(51.4 \pm 5.9 \%)$ and immature teratoma $(90.6 \pm 5.0 \%)$. Other substances - Methotrexate (Ebewe Artsnaym., Austria, $50.0 \mu \mathrm{g} / \mathrm{ml}$ ) and Gemcitabine (WeeEm-Gee Pharmaceuticals Pvt. Ltd., India, $2.0 \mu \mathrm{g} / \mathrm{ml}$ ) though were not included in the list of 
leading substances, often successfully shared with them the second or third position. However, in a case of anaplastic oligodendroglioma the latter was not effective. Moreover, in its presence the cells of pleomorphic xanthoastrocytoma like Etoposide ones demonstrated a paradoxical reaction - a statistically significant increase of survival potential. The same is with carboplatin. Maximum susceptibility to it is shown by document in the samples of four neoplasm, and first of all of atypical teratoid / rabdoid tumor and optic chiasm glioma to have lost $79.5 \pm 1.0$ and $78.9 \pm 4.1 \%$ viable units. These compounds are followed by Etoposide, which predominant efficacy was also recorded in three types of tumor cells, especially in glioblastoma.

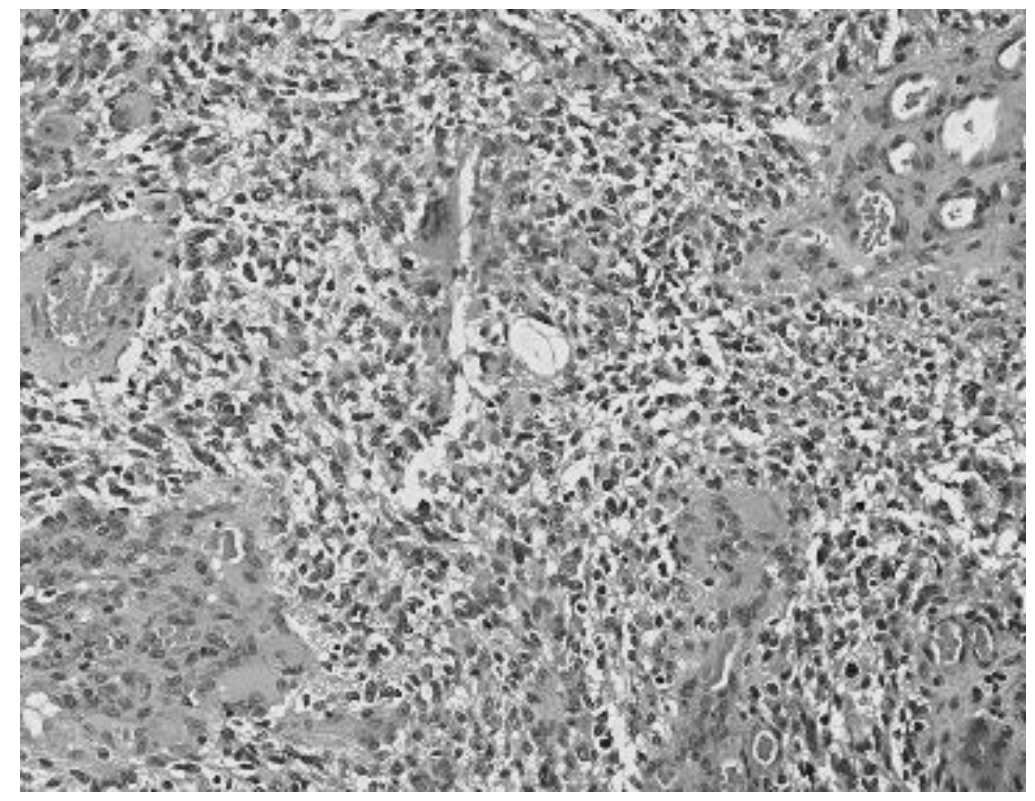

Fig. 4. Glioblastoma with marked vascular proliferation and the formation of glomerular structures.

It is right to note the following fact: culture objects manifested almost the same (competitive) sensitivity to two or more agents in virtually all cases, if one takes into consideration the closeness of a number of infected cells, differences of which were not included in the validation category. As for $\beta$-NGF, its superiority (although not statistically significant) over the cytostatic regarding a number of perished in vitro units occurred in biopsies of pilomixoid astrocytoma ( $47.6 \pm 1.3 \%$ vs. $40.9 \pm 11.4 \%$ of Cisplatin), medulloblastoma (Fig. 5 ) $(44.9 \pm 2.9$ vs. $41.6 \pm 8.5 \%$ from the same preparation), oligoastrocytoma (78.3 \pm 0.9 vs. $55.1 \pm$ 8.5\% of Etoposide) (Fig. $3 \mathrm{a}, \mathrm{b}, \mathrm{c})$ and ependymoma (62.4 \pm 6.0 vs. $58.6 \pm 4.4 \%$ of Carboplatin).

The efficiency of $\beta$-NGF $(68.2 \pm 0.5 \%)$ almost coincided with that of Cytarabine $(68.9 \pm$ $11.9 \%$ ), and under the contact with the cells of anaplastic astrocytomas (Fig. 6) (38.2 $\pm 2.3 \%$ ) reached the $2^{\text {nd }}$ position after for Cytarabine $(54.4 \pm 5.9 \%)$, pushing on the third place Carboplatin $(35.9 \pm 1.8 \%)$ when glioblastoma was applied to the cells the primary culture. In 
the contrast, the derivatives of pleomorphic xanthoastrocytoma responded to $\beta$-NGF by a significant increase in its resistance to the toxin (an increase of vitality). Their death was 13.6 $\pm 2.9 \%$ in relation to the fixed one in the tumor cells which were not subjected to any influence $-31.7 \pm 0.5 \%$, whereas the culture of ganglioglioma was generally indifferent to cytostatics.

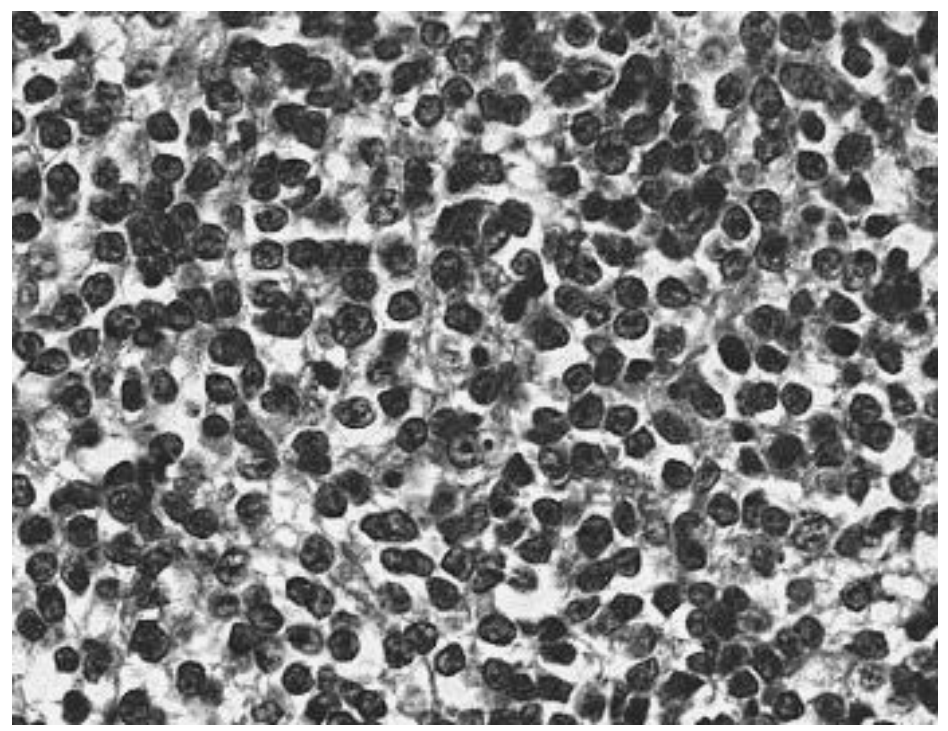

Fig. 5. Undifferentiated medulloblastoma

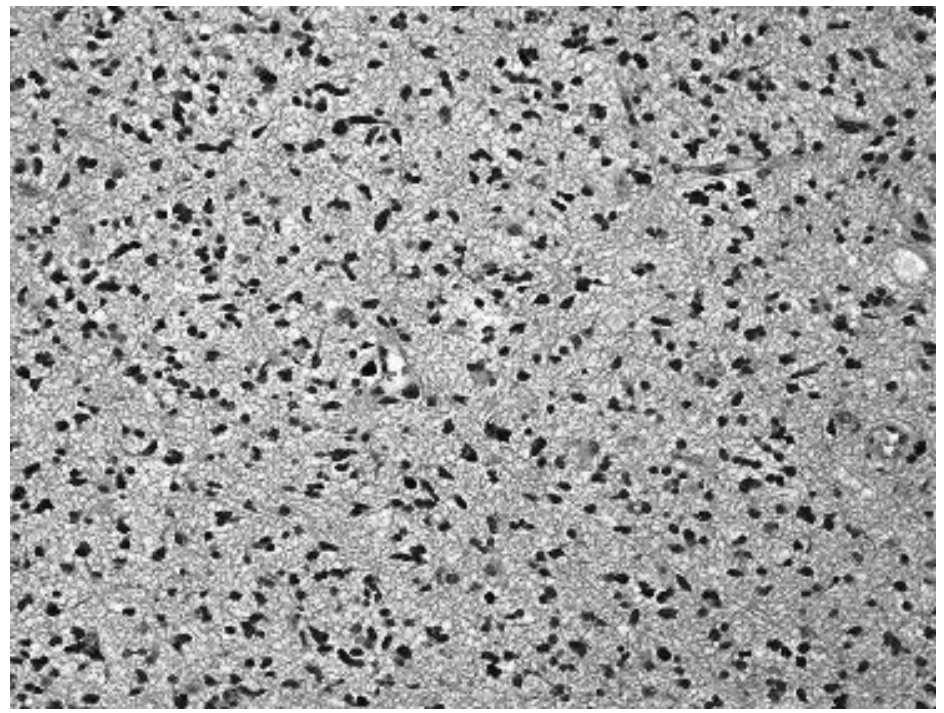

Fig. 6. Anaplastic astrocytoma. Moderate cellularity. Nuclear polymorphism 
The access to the analysis of a destructive influence of combined test compounds application, while keeping in mind the possibility of potentiation of their individual effects was the logical corollary from an analysis of the brought materials. It turned out that in most combinations (excluding $\beta$-NGF + Methotrexate in the case of pilocytic astrocytoma), a marked tendency of a destructive cellular reactions increase in comparison with those described in the isolated introduction of preparation) was observed. A combination of Cisplatin + Etoposide $(89.5 \pm 0.8 \%)$, Carboplatin + Cytarabine $(81.4 \pm 2.0 \%)$, Carboplatin + Etoposide $(69.2 \pm 3.0 \%)$ and Cisplatin + Carboplatin $(68.8 \pm 7.3 \%)$ for cells oligoastrocytoma, and Cisplatin + Carboplatin $(78.1 \pm 1.9 \%)$ and $\beta$-NGF + Cisplatin $(55.5 \pm 3.2 \%)$ shown with an example of cells of ganglioglioma was especially attractive in vitro conditions. In these cases, the combined effect of cytotoxic drugs significantly exceeded observed ones under individual applications of each component from every pair of drugs. It's worth noting that $\beta$-NGF, despite the decline of its performance in a variant of samples from oligoastrocytoma, tends as a rule to significantly increasing toxic effects on the tumor cells survival in a combination with cytotoxic drugs. This raises a question of reasonableness of the further research in terms of the simultaneous application of these agents. For the sake of fairness it should be emphasized that in any case of their combination one failed to reveal signs of synergy, where the reaction to the combination would have excelled the arithmetic sum of the personal effects, included as components in its structure. This can be conditioned by complex polymorphism of brain tumors, including dividing tumor cells and stem tumor cells at that. The survival of an even single cancer stem cell could lead to a recurrence of tumor metastasis and uncontrolled process in other parts of the central nervous system.

It is important to point out that varying selective affinity touched not only biopsy samples belonging to different types of tumors, but also tumors taken away from an absolutely analogous composition accordingly to histological compounds and a measure of tumor progression. For example, the maximum destruction of cultured cells was recorded against a background application Cytarabine $(68.3 \pm 6.9 \%, P<0.05)$, and to a lesser extent Cisplatin $(49.4 \pm 5.4 \%, \mathrm{P}<0.05)$, and Methotrexate $(39.7 \pm 7.2 \%, P<0.05)$ in three patients with medulloblastoma of the IV stage. The other chemotherapy drugs effect on cells of tumor had actually no difference in growth of cell culture without the application of cytostatic. This circumstance makes relevant carrying out a preliminary rapid assessment of individual susceptibility of patients to chemotherapeutic drugs with involvement of cultural systems. Moreover, it was possible to show by a document a certain correlation between the effectiveness of test compounds and the degree of malignancy at the same astrocytic nature of the tumors. Let us demonstrate this by the following examples. Thus Cisplatin (61.9 \pm $12.9 \%)$, Carboplatin $(53.8 \pm 7.9 \%)$ and Methotrexate $(47.0 \pm 7.2 \%)$ came into the triad of superior according to induction of cell lethality at the Ist stage. At the IInd stage Carboplatin $(57.9 \pm 5.9 \%)$, Methotrexate $(51.1 \pm 4.0 \%)$ and Cytarabine $(50.2 \pm 9.4 \%)$ occupied the dominant position. On the IIId - Cytarabine (54.4 $\pm 5.9 \%)$, Carboplatin (35.9 $\pm 1.8 \%)$ and Etoposide $(34.5 \pm 4.4 \%)$, and at the IVth - Cytarabine $(68.9 \pm 11.9 \%)$, Etoposide $(63.1 \pm 0.4 \%)$ and Gemcitabine $(61.5 \pm 1.7 \%)$. As a matter of fact the mentioned graduation should be viewed with a certain degree of conditionality, since statistically significant differences between the members of each triad could not be established. It's noteworthy, however, that $\beta$-NGF, occupying a relatively modest position in the first phase of malignancy acquired a tough competition $(68.2 \pm 0.5 \%)$ leading to the IVth stage of Cytarabine $(68.9 \pm 11.9 \%)$ and bunched over $(38.2 \pm 2.3 \%)$ from the $2^{\text {nd }}$ stage $(35.9 \pm 1.8 \%)$ of Carboplatin (please, bear in mind: at isolated applications of $\beta-\mathrm{NGF}$ ). 
The dependence of the destructive action of cytostatic and $\beta$-NGF also correlated with the age of the patients. Differences in digital indicators which characterize the percentage of cell loss of primary tumor culture in vitro gave evidence of the complex mechanisms of interaction between tumor cells with cytotoxic drugs coming in the triad of the most active compounds. So, at the child age under 3 years old the tumor generating effect was observed in Carboplatin $(59.7 \pm 4.1 \%)$, Cisplatin $(51.4 \pm 4.5 \%)$ and Cytarabine $(48.3 \pm 2.4 \%)$, and at the age from 4 to 6 years old $\beta$-NGF $(63.2 \pm 4.8 \%)$, Cisplatin $(62.3 \pm 7.6 \%)$ and Methotrexate $(49.4$ $\pm 5.8 \%$ ) were in the lead. At the age from 7 to 10 years old the toxic substances rating looked like follows: Carboplatin (38.1 \pm 8.8$), \beta$-NGF $(27.1 \pm 6.1 \%)$ and Methotrexate $(26.2 \pm 3.1 \%)$. At the age from 11 to 15 years old Methotrexate moved to the first position $(56.0 \pm 3.8 \%)$, slightly ahead of Carboplatin (54.4 $\pm 2.9 \%)$ and Cisplatin $(53.6 \pm 3.7 \%)$. $\beta$-NGF, taking the first place in terms of suppression of cell survival in the intermediate age groups, showed in the fourth (most mature) group an inverted effect, which increased cell survival significantly $(13.3 \pm 2.9 \%)$ compared with control $(32.9 \pm 3.0 \%)$.

Experiments conducted in vitro demonstrated once again the well-known position of the highest individual sensitivity of glioma to cytostatics. No one has ever managed to fix the same sequence in the effectiveness of tumor destroying the action by the protocol approved cytostatic at absolutely identical histological diagnoses. Registered dependence of differences of effects from sex and age did not permit to explain the inner workings of such a high individual sensitivity of glioma to chemotherapy. It is obvious that one of explanations for this phenomenon can be a different degree of presence of stem tumor cells in tumor tissue. The high stability of stem tumor cells to damaging agents is well known.

We are therefore got interested in the effect of enhancing the anticancer effect of cytostatics and NGF presence. As a hypothesis we can suggest that a strengthening of an anticancer effect of a combination of chemotherapeutic drugs and NGF is determined by an influence of drugs not only on dividing tumor cells but also on stem tumor cells. If it is so, then it is advisable to try to test different combinations of chemotherapy with cytotoxic substances of a new generation. In particular, we talk about the heterocyclic compounds, many of which are capable of inhibiting the intracellular tyrosine kinas path and, thus, to initiate the mechanisms of apoptosis in tumor tissue. The use of nanoparticles, in particular, Fullerenes or Dendrimers seems making a promise for these tasks. More details will be discussed below. There are many more challenges in oncology on the way to more effective cancer therapy. The well known high toxicity of chemotherapeutic drugs for all organs and systems of a living organism stimulates scientists and oncologists to find ways of reducing the general toxic action of cytostatic, and maintaining their anti-tumor effect. The result in these experiments on primary culture oligoastrocytoma cerebellar vermis can be given as an example of such a design. The data are presented in Table 1.

The following fact draws attention at analyzing the data. In comparison with the natural death of cells the addition of Carboplatin, Methotrexate or Cisplatin was accompanied by an increase in the percentage of dead cells in a Petri dish from 35\% to $47 \%$ in the control (when cells of primary culture of oligoastrocytoma cerebellar vermis were developing in the culture medium without any contact with the chemotherapy). The combination of one of these three chemotherapy drugs with Nerve Growth Factor under decreasing doses of the cytostatic factor led in 10 times to the preservation or even an increase of the cytostatic effect (Table 1). The effect of two cytostatics - Carboplatin and Methotrexate increased especially 
demonstratively. If you are not going to speculate on possible mechanisms of this phenomenon, then one is competent to conclude that the concentration of cytostatic can be significantly reduced in situations of combined use of chemotherapy with NGF. This reduction of dosage will be accompanied by a decline in general toxic action of chemotherapy drugs (which is critical for every cancer patient) and a persistence of the cytostatic action in relation to tumor cells (what is critical for a patient and a physician). A similar cytotoxic effect was observed earlier while applying diamond-like structures (Chekan et al., 2009). Experiments in vitro decreased survival of rat C6 glioma cells in the presence of implants made of titanium alloy VT-16. Putting diamond-like carbon coatings on the alloy VT-16 was accompanied with an increase in the percentage of cell death on the fifth day of cultivation, compared with the control: $39.9 \pm 2.1 \%$ and $5.4 \pm 0.3 \%$, respectively. A more significant decrease in mitotic activity and cell viability was observed when C6 glioma cells contacted with diamond-like carbon coating, comprising silver nanoparticles. The number of cell destruction of glioma C6 at contact with the diamond-like carbon covering, including up to $3.5 \%$ Silver nanoparticles, made $53.7 \pm 2.1 \%$, and at doping up to $6.7 \%$ Silver the cell destruction reached $66.7 \pm 3.2 \%(\mathrm{P}<0.05)$ in comparison with the control. Hence, the maximum toxic effect in regard to $\mathrm{C} 6$ glioma was detected in samples coated with diamond-like film, including silver nanoparticles. Similar results were obtained in the application of diamond coatings on the primary culture of human gliomas. If the surface of titanium samples with a diamond-like coatings included additional silver nanoparticles, the cytotoxic effect on the second day after exposure of cells of oligodendrogliomas with the surface of the samples would be disastrous for the viability of these cells. As it is shown in Fig. 7 A, processes of proliferation are continuing in tumor cells outside the titanium samples, while at the site location on a Petri dish of titanium sample almost all cells died (Fig. 7 B).

\begin{tabular}{|c|c|}
\hline Title Series & Cell death, $\%$ \\
\hline Control & $12.5 \pm 4.2$ \\
\hline Carboplatin $4.0 \mu \mathrm{g} / \mathrm{ml}$ & $35.3 \pm 0.9^{*}$ \\
\hline Carboplatin $0.4 \mu \mathrm{g} / \mathrm{ml}+\beta \mathrm{NGF} 0.1 \mu \mathrm{g} / \mathrm{ml}$ & $57.1 \pm 12.5^{*}$ \\
\hline Methotrexate $50.0 \mu \mathrm{g} / \mathrm{ml}$ & $43.7 \pm 8.6^{*}$ \\
\hline Methotrexate $5.0 \mu \mathrm{g} / \mathrm{ml}+\beta \mathrm{NGF} 0.1 \mu \mathrm{g} / \mathrm{ml}$ & $72.4 \pm 2.5^{*}$ \\
\hline Cisplatin $1.0 \mu \mathrm{g} / \mathrm{ml}$ & $47.4 \pm 3.0^{*}$ \\
\hline Cisplatin $0.1 \mu \mathrm{g} / \mathrm{ml}+\beta \mathrm{NGF} 0.1 \mu \mathrm{g} / \mathrm{ml}$ & $50.0 \pm 8.1^{*}$ \\
\hline
\end{tabular}

Table 1. Percentage of cell death oligoastrocytoma cerebellar vermis at a combination of different doses of cytostatics with Nerve Growth Factor (NGF). (The asterisk * denotes the reliability of $P<0.05$ ) 


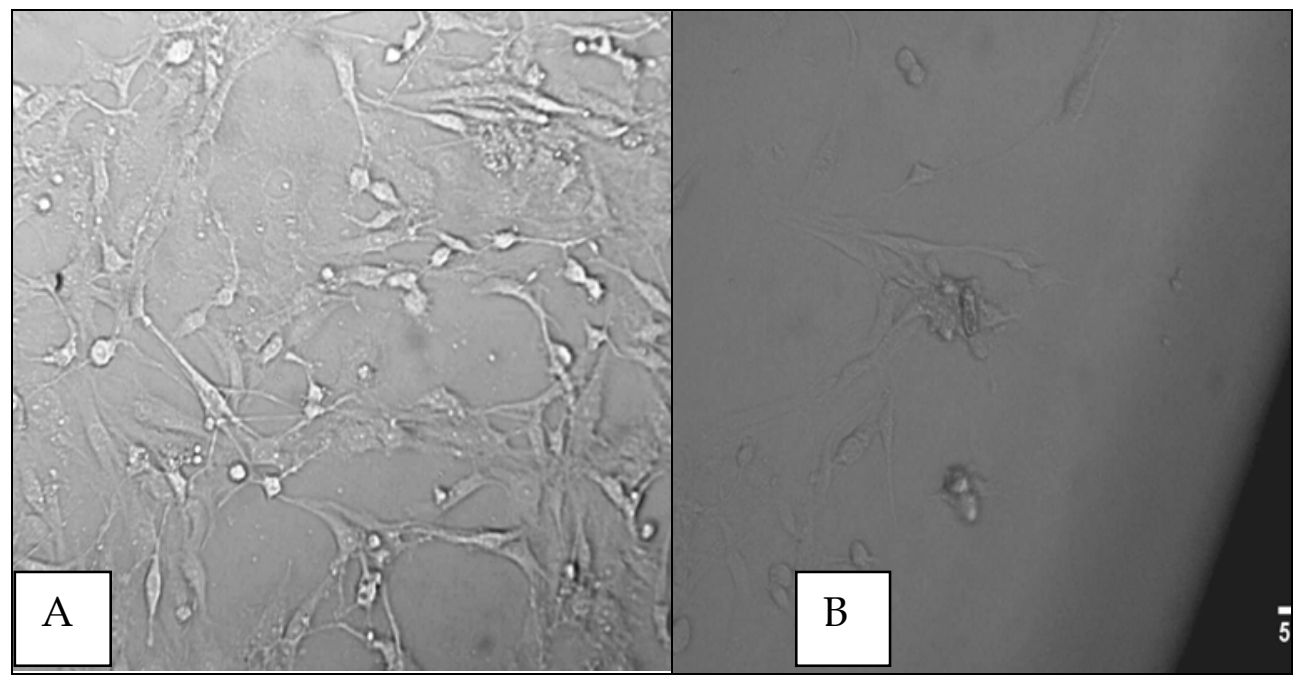

Fig. 7. Oligodendrogliomas cell distribution in twenty-four hours at $40 \mathrm{~mm}$ from the titanium sample with diamond-like coating containing silver nanoparticles (A), and at $1 \mathrm{~mm}$ from the edge of the sample (B)

It was established that if the titanium samples were coated with titanium dioxide $\left(\mathrm{TiO}_{2}\right)$, a cytotoxic effect of these samples (Fig. 8 A and B) would not differ from a cytotoxic effect of those which coating consisted of silver nanoparticles.

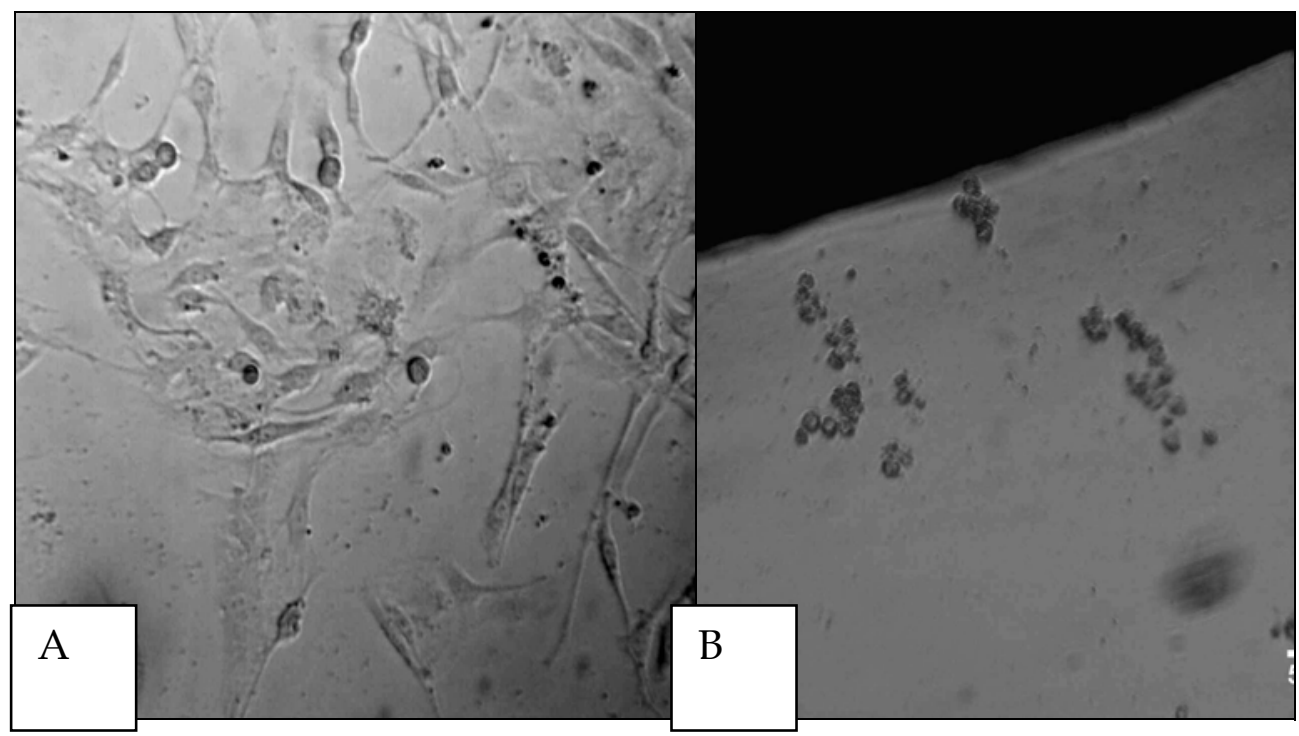

Fig. 8. Oligodendrogliomas cell distribution in twenty-four hours at $40 \mathrm{~mm}$ from the titanium sample with titanium dioxide $\left(\mathrm{TiO}_{2}\right)(\mathrm{A})$, and at $1 \mathrm{~mm}$ from the edge of the sample (B) 
The highest potentiating effect of the combination of chemotherapy and nanoparticles was obtained by the application of Dendrimers. Series of experiments of a Cisplatin combination with PAMAM on the primary culture of medulloblastoma are in Table 2.

\begin{tabular}{|c|c|}
\hline Title Series & Cell death, $\%$ \\
\hline Control & $20.7 \pm 3.3$ \\
\hline Cisplatin $1.0 \mu \mathrm{g} / \mathrm{ml}$ & $67.6 \pm 7.4^{*}$ \\
\hline Cisplatin $1.0 \mu \mathrm{g} / \mathrm{ml}+\beta \mathrm{NGF} 0.1 \mu \mathrm{g} / \mathrm{ml}$ & $49.2 \pm 6.8^{*}$ \\
\hline PAMAM $30 \mathrm{mM}(10.0 \mu \mathrm{l})$ & $45.5 \pm 6.7^{*}$ \\
\hline Cisplatin $1.0 \mu \mathrm{g} / \mathrm{ml}+$ PAMAM $30 \mathrm{mM}$ & $92.7 \pm 4.9^{*}$ \\
$(10.0 \mu \mathrm{l})$ & \\
\hline $\begin{array}{c}\text { Cisplatin } 0.1 \mu \mathrm{g} / \mathrm{ml}+\text { PAMAM } 30 \mathrm{mM} \\
(10.0 \mu \mathrm{l})\end{array}$ & $98.4 \pm 1.5^{*}$ \\
\hline
\end{tabular}

Table 2. Percentage of cell death medulloblastoma IV at a combination of different doses of Cisplatin with Polyamidoamine (PAMAM) Dendrimer (the asterisk * denotes the reliability of $P<0.05)$

As it is seen in Table 2, the percentage of cell death of malignant medulloblastoma increased significantly in primary culture under the action of Cisplatin and paradoxically reduced by a combination of Cisplatin with NGF. This fact does illustrate once again the high specificity of each particular tumor in each patient, what determines the choice of individual treatment strategy in each case. This choice should be guided by research data and the sensitivity of cells in primary culture in vitro.

Application of PAMAM $30 \mathrm{mM}(10.0 \mu \mathrm{l})$ in a Petri dish was accompanied by increased cell death in comparison with control ones. In principle, the anticancer effect of Dendrimer is described in literature but has not been studied in detail (Bei et al., 2010). At this stage we have only stated such an action of PAMAM. Surprisingly a stable toxic effect of a combination Cisplatin with PAMAM was demonstrated at using two different concentrations of chemotherapeutic drugs (Table 2). The anticancer effect of this drug combination ranged from $92 \%$ to $98 \%$ (Fig. 9, and Fig. 10). Therefore it is very important to find such a combination chemotherapy with growth factors and nanoparticles, which would reduce the dose of cytostatics, when we tried to determine the sensitivity of individual tumor in vitro to cytostatic in the next phase of the research. At the same cytotoxic effect of substances used must be maintained at maximum levels. Dendrimers belong to a class of polymeric compounds whose molecules have a large number of branches. At their acquisition a number of branches of the molecule increase with every elementary act of growth. As a result, the shape and rigidity of the molecules change with increasing molecular weight of these compounds, what is usually accompanied with changes in physical and chemical properties of Dendrimers. Inside Dendrimers cavities are formed which can be filled in with a variety of substances, such as cytostatic. This ability of Dendrimers was one of the factors to determine the decision to use them for enhancement of their anticancer effect of chemotherapy.

The paper drew attention also to other compounds that might be effective against tumor growth. The input material for the synthesis of heterocyclic compounds was 1,2-azole-3carboxylic acids, which were consistently converted into azides or carbamide. Implemented computer modeling of ligand-protein complexes of carbamide was carried out in the framework of the methods of molecular mechanics using the program Dock 6.4 and USF 
Chimera. Evaluation of energy characteristics of the van der Waals and electrostatic interaction suggests the possibility of efficient binding of 1,2-azole ligand protein. These studies helped to choose the best version of heterocyclic compounds (Carbamide), which application in a combination with cytostatic agents and Nerve Growth Factor allowed reducing the dose of the cytostatic factor in 10 times at maintaining in vitro the tumor generating effect on primary cell cultures. There are the above listed drawings as a demonstration.

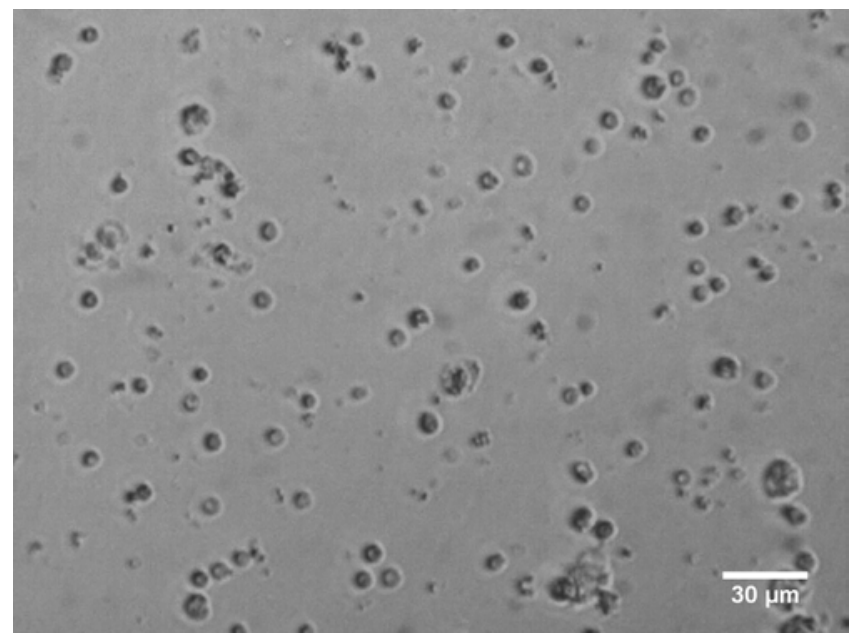

Fig. 9. Atypical teratoid / rhabdoid tumor cells remaining in a day after the application of Cisplatin $(1.0 \mu \mathrm{g} / \mathrm{ml}), \beta-\mathrm{NGF}(0.1 \mu \mathrm{g} / \mathrm{ml})$, Polyamidoamine Dendrimer $(30 \mathrm{mM}, 10.0 \mu \mathrm{l})$

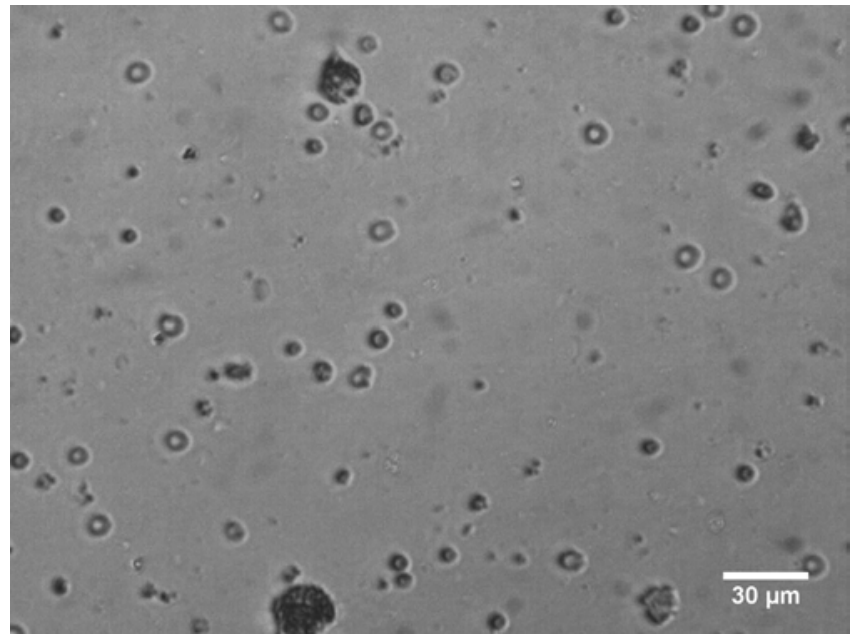

Fig. 10. Atypical teratoid / rhabdoid tumor cells remaining in a day after the application of Cisplatin $(0.1 \mu \mathrm{g} / \mathrm{ml}), \beta$-NGF $(0.1 \mu \mathrm{g} / \mathrm{ml})$, Polyamidoamine Dendrimer $(30 \mathrm{mM}, 10.0 \mu \mathrm{l})$ 
Anticancer effects of heterocyclic compounds in one more series of experiments were approved (Figs. 11-13). The Fig. 11 shows the primary tumor cells of pilocytic astrocytoma in two days after passage. Figure 12 shows primary tumor cells pilocytic astrocytoma in two days after the addition of Azide at a concentration of $1.0 \mathrm{mg} / \mathrm{ml}$. Figure 13 shows primary tumor cells pilocytic astrocytoma in two days after the addition of Carbamide at a concentration of $1.0 \mathrm{mg} / \mathrm{ml}$. Toxic properties of Azides and Carbamide can be explained by their ability to inhibit the tyrosine kinase pathway. This mechanism can be implemented in the subsequent initiation of apoptosis in tumor cells.

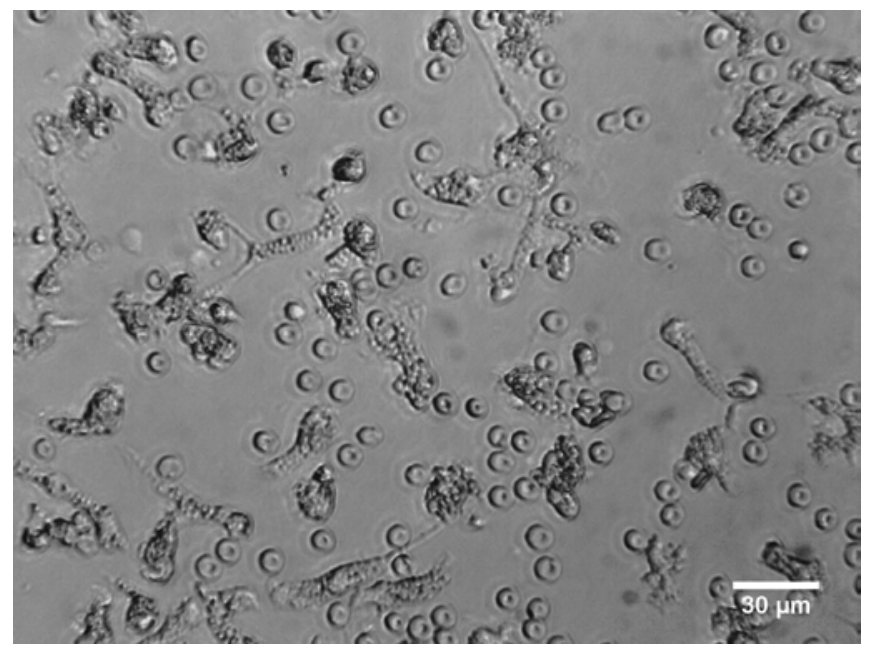

Fig. 11. Pilocytic astrocytoma cells in a day after passage

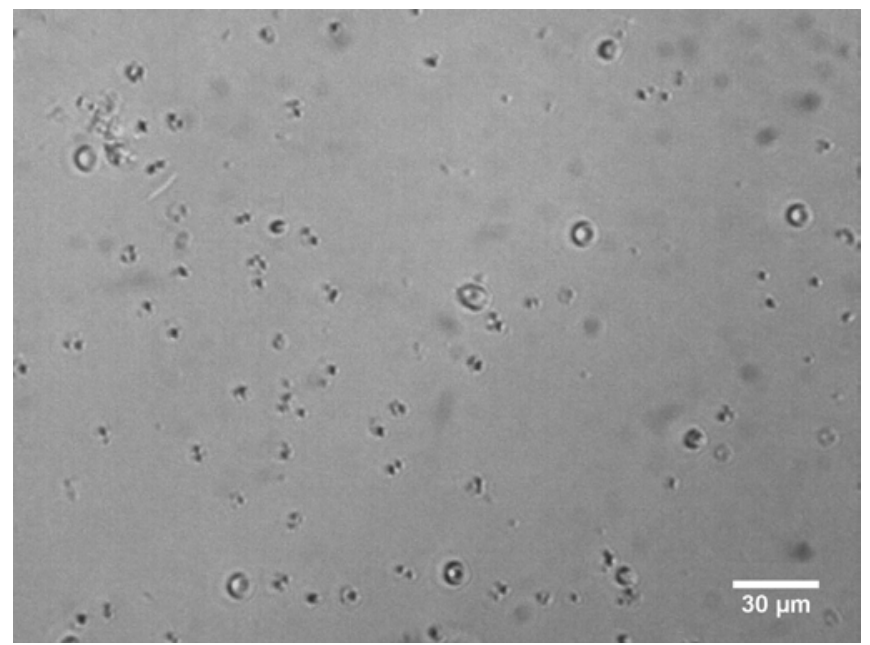

Fig. 12. Pilocytic astrocytoma cells in a day after application of Azide at a concentration of $1.0 \mathrm{mg} / \mathrm{ml}$ 


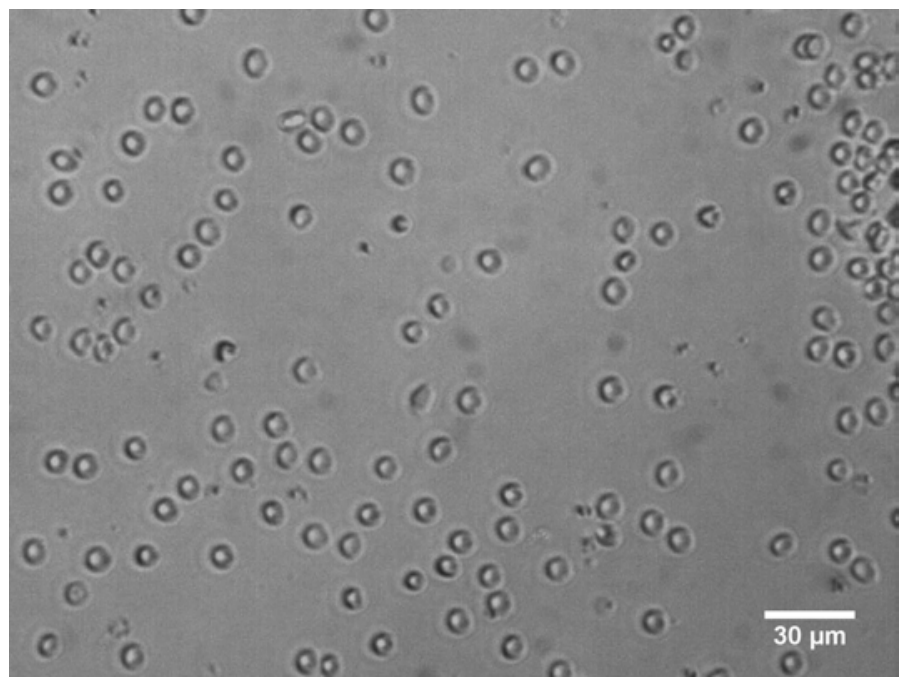

Fig. 13. Pilocytic astrocytoma cells in a day after application of Carbamide at a concentration of $1.0 \mathrm{mg} / \mathrm{ml}$

\section{Conclusion}

The data obtained are the basis to discuss several aspects of increasing the chemotherapy effectiveness problem. Being general toxic poisons in the action by their nature, chemotherapy drugs come out as an essential attribute of anticancer therapy in accordance with the majority of the approved treatment protocols. There are no alternatives to their use considering the presence of appropriate evidence. In such a case, how can one reduce the general antineoplastic action of cytostatics and keep their strong anticancer effect? The anticancer effect is under discussion in respect of not only dividing tumor cells, but also stem tumor cells. The advantage of a mutual use of cytostatics and NGF compared with their individual use was confirmed in the work. It puts on the agenda the top-priority intensively developing problem, that is of improving the permeability of the blood-brain barrier at systemic application of chemotherapy and the search for "circuitous" ways to the desired delivery of biologically active compounds to tumor tissues (Alam et al., 2010; Chen et al., 2011; Gerstner \& Fine, 2007). In order to implement the first plan several directions are supposed. One of them is to attract hyperosmotic solutions containing histamine, bradykinin, mannitol and so on, which will contribute to achieving the cytostatic targets in the brain at their systematic putting into operation (Kemper et al., 2004; Xie et al., 2005). But the transient opening by them of the entrance gate provides at the same time an opportunity of entering via them for the neurotoxic substance what is especially dangerous in case of a more complex operative procedure of an intracarotid infusion of chemotherapeutic agents. This may be accompanied by disorders of speech, movement, visual perception.

One more trend is based on creation of conjugates of an active commencement with proteins, which are able to recognize the integral components of cerebrovascular structures, such as antibodies to the receptor ferritin in relation to the NGF. This ensures its effectiveness in a rank of low concentrations. The simultaneous application of anticancer 
drugs with inhibitors of a large glycoprotein $\mathrm{P}$, which prevents the movement of cytotoxic drugs through the blood-brain barrier (Gerstner \& Fine, 2007; Kemper et al., 2004) is promising. Preclinical trials with Paclitaxel have confirmed the perspectives of such a method, making reasonable transition to clinical trials.

Attempts of a different kind are being made, namely the involvement of the bradykinin analog BMP-7, endowed with a more extended half-life period and with selectivity in respect to the receptor B2 in comparison with the being endogenously synthesized compound (Kemper et al., 2004; Ta et al., 2009; Xie et al., 2005). Being associated with them, BMP-7 leads to the opening of calcium channels in cells, an increase in their level of free cations. That leads to a reaction of endothelial cells and to weakening of intercellular contacts. The vascular permeability increases in addition. The recorded concentrations of growth factors were achieved in 30 minutes with the highest representation in the striatum, hippocampus, cerebral cortex and relatively low concentrations in the olfactory bulb, cerebellum and brainstem at joint custody of NGF and BMP-7 into stabilized liposomes, which are smaller than $100 \mathrm{~nm}$. There was a good agreement between the permeability coefficient of the drug and its targeted action (Xie et al., 2005) at that. Under intracarotid administration of BMP-7 with Carboplatin in rat models of gliomas such a combination has significantly reduced the number of cytostatic normally used in humans. Phase II in clinical trials conducted on 87 patients with recurrence of malignant gliomas recorded a noticeable advantage of processing BMP-7 + Carboplatin before individually using only Carboplatin.

The advances in molecular biology and genetic engineering, which ensured the implementation of experimental and clinical use of low molecular weight peptides, proteins, oligonucleotides, monoclonal antibodies, etc. (Kruttgen et al., 2006; Xie et al., 2005) contributed to considerable progress in the development of a "roundabout" ways of delivery of drugs. In total they have created a fertile ground not only for in-depth understanding the basic mechanisms of carcinogenesis, but also simultaneously for widening the means of early diagnosis, the front of anticancer attack and optimization of medical schemes.

In a series of widely exploited methods there is a stereotactic implantation in the bed, formed after excision of tumor, indifferent biodegradable polymer substrates, impregnated in that or another way with an active principle. In this case, the cytostatic penetrates in measured doses into the surrounding tissue during a long period of time and destroy the remaining infected cells (Kemper et al., 2004; Ta et al., 2009). The concentration of drugs, developed in this case, can exceed observed ones with intravenous injection from 4 to 1200 times. In one of the clinical trial performed on 222 adult patients with recurrent gliomas mortality of persons who were within 6 months receiving such a method Cisplatin was $44 \%$ versus $67 \%$ among patients treated with placebo $(P<0.02)$.

The use of polymer capsules can also supply the brain with cells (transfected with viral vectors) which express a particular desired target gene which products act targeteous on the relevant parts of oncogenesis. The primary fibroblasts, astrocytes, ependimocytes, stem or progenitor cells serve as usual objects. For example, subclones Cyclin-Dependent Kinase 2 Interacting Protein (CINP) releasing in vitro NGF at $2 \mathrm{ng} / \mathrm{h} / 10^{-5}$ cells over 10 weeks was isolated from conventionally immortalized progenitor neuroblasts of the central nervous system of rat embryos with embedded DNA of growth factors. Being introduced into the brain such cells survived well, migrated at a distance of $15 \mathrm{~mm}$ from the implant site and integrated with the host tissue without any signs of growth or tumor formation.

Thus, we can conclude: 
i. Sensitivity of glioma cells to chemotherapeutic agents, Nerve Growth Factor, and Dendrimers, Diamond like coated samples, heterocyclic compaunds in vitro depends on the origin, histological type tumors, the degree of malignancy, age and individual characteristics of patients;

ii. Combined application of Nerve Growth Factor and chemotherapy increases the percentage of dying in a culture of cellular elements;

iii. A complementary effect of Nerve Growth Factor appears to enhance cytotoxic effects of chemotherapy. This addictiveness reduces the effective dose of cytotoxic drugs in more than 10 times;

iv. The presence of growth factor and/or Dendrimers, heterocyclic compounds do reduce the toxic dose of the chemotherapeutic drugs simultaneously maintaining a high cytostatic effect;

v. Detection in vitro of high individual sensitivity of brain tumors to cytostatics confirms the hypothesis concerning polymorphism in mechanisms of carcinogenesis;

vi. It is appropriate to take into account the results of experiments in order to determine the sensitivity of tumor cells of primary culture to cytostatic drugs in the development of new specialized treatment protocols for brain tumors (mono- or polychemotherapy).

\section{Acknowledgment}

We express our deep appreciation to Professor Joseph Zalutsky for supporting this work, and Professor Eugene Cherstvoy for the attention and assistance in the histological studies.

\section{References}

Alam, M.I.; Beg, S.; Samad, A.; Baboota, S.; Kohli, K.; Ali, J.; Ahuja, A. \& Akbar, M. (2010). Strategy for effective brain drug delivery. European Journal of Pharmaceutical Sciences, Vol.40, No.5, pp. 385-403.

Alomar, S.A. (2010). Clinical manifestation of central nervous system tumor. Seminars in Diagnostic Pathology, Vol.27, No.2, pp. 97-104.

Antonelli, A.; Lenzi, L.; Nakagawara, A.; Osaki, T.; Chiaretti, A. \& Aloe, M. (2007). Tumor suppressor proteins are differentially affected in human ependymoblastoma and medulloblastoma cells exposed to nerve growth factor. Cancer Investigation, Vol.25, No.2, pp. 94-101.

Barnes, M.; Eberhart, C.G.; Collins, R. \& Tihan, T. (2009). Expression of p75NTR in fetal brain and medulloblastomas: evidence of a precursor cell marker and its persistence. Journal of Neurooncology, Vol.92, No.2, pp. 193-201.

Beebe, J.S.; Jani, J.P.; Knauth, E.; Goodwin, P.; Higdon, C.; Rossi, A.M.; Emerson, E.; Finkelstein, M.; Floyd, E.; Harriman, S.; Atherton, J.; Hillerman, S.; Soderstrom, C.; Kou, K.; Gan,t T.; Noe, M.C.; Foster, B.; Rastinejad, F.; Marx, M.A.; Schaeffer, T.; Whalen, P.M. \& Roberts,W.G. (2003). Pharmacological characterization of CP547,632, a novel vascular endothelial growth factor receptor-2 tyrosine kinase inhibitor for cancer therapy. Cancer Research, Vol.63, No.21, pp. 7301-7309.

Bei, D.; Meng, J. \& Youan, B.B. (2010). Engineering nanomedicines for improved melanoma therapy: progress and promises. Nanomedicine (Lond), Vol.5. No.9. pp. 1385-1399.

Blum, R. \& Konnerth, A. (2005). Neurotrophin-mediated rapid signaling in the central nervous system: mechanisms and functions. Physiology, Vol.20, pp. 70-78. 
Brossard, D.; El Kihel, L.; Clément, M.; Sebbahi, W.; Khalid, M.; Roussakis, C.; Rault, S. (2010). Synthesis of bile acid derivatives and in vitro cytotoxic activity with proapoptotic process on multiple myeloma (KMS-11), glioblastoma multiforme (GBM), and colonic carcinoma (HCT-116) human cell lines. European Journal of Medicinal Chemistry, Vol.45, No.7, pp. 2912-2918.

Charles, N.A.; Holland, E.C.; Gilbertson, R.; Glass, R.; Kettenmann, H. (2011). The brain tumor microenvironment. Glia. Vol.59, No.8, pp. 1169-1180.

Chekan, N.M.; Beleauski, N.M.; Akulich, V.V.; Pozdniak, L.V.; Sergeeva, E.K.; Chernov, A.N.; Kazbanov, V.V. \& Kulchitsky, V.A. (2009). Biological activity of silver-doped DLC films, Diamond \& Related Materials, Vol.18. pp. 1006-1009.

Chen, C.H.; Chang, Y.J.; Ku, M.S.; Chung, K.T., Yang, J.T. (2011). Enhancement of temozolomide-induced apoptosis by valproic acid in human glioma cell lines through redox regulation. The Journal of Molecular Medicine, Vol.89, No.3, pp. 303315.

Collins, V.P. (2004). Brain tumors: classification and genes. Journal of Neurology and Neurosurgical Psychiatry, Vol.75, Supplement 2, pp. 2-11.

Cragnolini, A.B. \& Friedman, W.J. (2008). The function of p75NTR in glia. Trends Neuroscience, Vol.31, No.2, pp. 93-104.

Davis, M.E.; Mulligan Stoiber, A.M. (2011). Glioblastoma multiforme: enhancing survival and quality of life.Clinical Journal of Oncology Nursing, Vol.15, No.3, pp. 291-297.

Dunkel, I.J.; Gardner, S.L.; Garvin, J.H. Jr.; Goldman, S.; Shi, W. \& Finlay, J.L. (2010). Highdose carboplatin, thiotepa, and etoposide with autologous stem cell rescue for patients with previously irradiated recurrent medulloblastoma. Neurooncology, Vol.12, No.3, pp. 297-303.

Erdlenbruch, B.; Jendrossek, V.; Eibl, H.; Lakomek, M. (2000). Transient and controllable opening of the blood-brain barrier to cytostatic and antibiotic agents by alkylglycerols in rats. Experimental Brain Research, Vol.135, No.3, pp. 417-422.

Evangelopoulos, M.E.; Weis, J. \& Kruttgen, A. (2004). Neurotrophin effects on neuroblastoma cells: correlation with Trk and p75NTR expression and influence of Trk receptor bodies. Journal of Neurooncology, Vol.66, No.1-2, pp. 101-110.

Frank, N.Y.; Schatton, T. \& Frank, M.H. (2010). The therapeutic promise of the cancer stem cell concept, Journal of Clinical Investigation, Vol.120, No.1, pp. 41-50.

Gerstner, E.R. \& Fine, R.L. (2007). Increased permeability of the blood-brain barrier to chemotherapy in metastatic brain tumors: establishing a treatment paradigm. Journal of Clinical Oncology, Vol.25, No.16, pp. 2306-2312.

Hirose, Y.; Yoshida, K. (2006). Chromosomal abnormalities subdivide neuroepithelial tumors into clinically relevant groups. Keio Journal of Medicine, Vol.55, No.2, pp. 52-58.

Kang, C.; Yuan, X.; Li, F.; Pu, P.; Yu, S.; Shen, C.; Zhang, Z.; Zhang, Y. (2010). Evaluation of folate-PAMAM for the delivery of antisense oligonucleotides to rat C6 glioma cells in vitro and in vivo. The Journal of Biomedical Materials Research A. Vol.93, No.2, pp. 585-594.

Kemper, E.M.; Boogerd, W.; Thuis, I.; Beijnen, J,H, \& van Tellingen, O. (2004). Modulation of the blood-brain barrier in oncology: therapeutic opportunities for the treatment of brain tumours? Cancer Treatment Reviews, Vol.30, No.5, pp. 415-423.

Krúttgen, A.; Schneider, I. \& Weis, J. (2006). The dark side of the NGF family: neurotrophins in neoplasias. Brain Pathology, Vol.16, No.4, pp. 304-310. 
Liu, Y.; Li, C.; Lin, J. (2010). STAT3 as a Therapeutic Target for Glioblastoma. Anticancer Agents in Medicinal Chemistry, Vol.10, No.7, pp. 512-519.

Morgan, M.T.; Nakanishi, Y.; Kroll, D.J.; Griset, A.P.; Carnahan, M.A.; Wathier, M.; Oberlies, N.H.; Manikumar, G.; Wani, M.C.; Grinstaff, M.W. (2006). Dendrimer-encapsulated camptothecins: increased solubility, cellular uptake, and cellular retention affords enhanced anticancer activity in vitro. Cancer Research, Vol.66, No.24, pp. 1191311921.

Myung, J.; Cho, B.K.; Kim, Y.S. \& Park, S.H. (2010). Snail and Cox-2 expressions are associated with WHO tumor grade and survival rate of patients with gliomas, Neuropathology, Vol.30, No.3. pp. 224-231.

Nakagawara, A. (2001). Trk receptor tyrosine kinases: a bridge between cancer and neural development. Cancer Letters, Vol.169, No.2, pp. 107-114.

Nicholas, M.K.; Lukas, R.V.; Chmura, S.; Yamini, B.; Lesniak, M.; Pytel, P. (2011). Molecular heterogeneity in glioblastoma: therapeutic opportunities and challenges. Seminars in Oncology, Vol.38, No.2, pp. 243-253.

Poluha, W.; Poluha, D.K. \& Ross, A.H. (1995). TrkA neurogenic receptor regulates differentiation of neuroblastoma cells. Oncogene, Vol.10, No.1, pp. 185-189.

Rosenfeld, A.; Kletzel, M.; Duerst, R.; Jacobsohn, D,; Haut, P.; Weinstein, J.; Rademaker, A.; Schaefer, C.; Evans, L.; Fouts, M. \& Goldman S. (2010). A phase II prospective study of sequential myeloablative chemotherapy with hematopoietic stem cell rescue for the treatment of selected high risk and recurrent central nervous system tumors. Journal of Neurooncology, Vol.97, No.2, pp. 247-255.

Schatton, T.; Frank, M.H. (2009). Antitumor immunity and cancer stem cells, Annals of the New York Academy of Sciences, Vol.1176, pp. 154-169.

Schatton, T.; Frank, N.Y.; Frank, M.H. (2009). Identification and targeting of cancer stem cells, Bioessays, Vol.31, No.10, pp. 1038-1049.

Ta, H.T.; Dass, C.R.; Larson I.; Choong, P.F.; Dunstan, D.E. (2009). A chitosan hydrogel delivery system for osteosarcoma gene therapy with pigment epitheliumderived factor combined with chemotherapy. Biomaterials, Vol.30, No.21, pp. 4815-4823.

Van den Eynde, M.; Baurain, J.F.; Mazzeo, F.; Machiels, J.P. (2011). Epidermal growth factor receptor targeted therapies for solid tumors. Acta Clinica Belgica, Vol.66, No.1, pp. 10-17.

Vega, J.A.; Garcia-Suarez, O.; Hannestad, J. ; Pérez-Pérez, M.; Germanà, A. (2003).Neurotrophins and immune system. Journal of Anatomy, Vol.203, No.1, pp. 1-19.

Vinores, S.A.; Perez-Polo, J.R. (1983). Nerve growth factor and neural oncology. Journal of Neuroscience Research. Vol.9, No.1, pp. 81-100.

Waite, C.L.; Roth, C.M. (2009). PAMAM-RGD conjugates enhance siRNA delivery through a multicellular spheroid model of malignant glioma. Bioconjugate chemistry. Vol.20, No.10, pp. 1908-1916.

Xie, Y.; Ye, L.; Zhang, X.; Cui, W.; Lou, J.; Nagai, T.; Hou, X. (2005). Transport of nerve growth factor encapsulated into liposomes across the blood-brain barrier: In vitro and in vivo studies. Journal of Control Release, Vol.105, No.1-2, pp. 106-119.

Yaeger, M.J.; Koestner, A.; Marushige, K.; Marushide, J. (1992). The use of nerve growth factor as a reserve transforming agent for the treatment of neurogenic tumors: in vivo results. Acta of Neuropathology, Vol. 83, No 6, pp. 624-629. 
Yamaguchi, Y.; Tabata, K.; Asami, S.; Miyake, M.; Suzuki, T. (2007). A novel cyclophane compound? CPPy, facilitates NGF-induced TrkA signal transduction and induces cell differentiation in neuroblastoma. Biological Pharmaceutical Bulletin, Vol.30, No.4, pp. 638-643. 


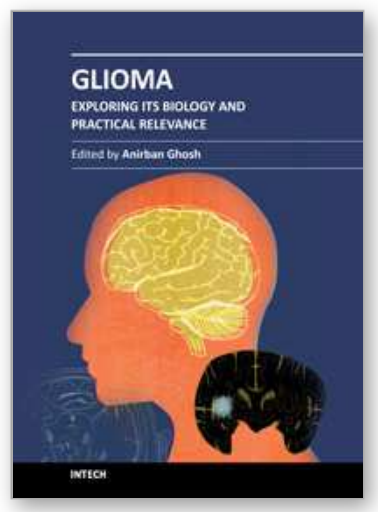

\author{
Glioma - Exploring Its Biology and Practical Relevance \\ Edited by Dr. Anirban Ghosh
}

ISBN 978-953-307-379-8

Hard cover, 486 pages

Publisher InTech

Published online 02, November, 2011

Published in print edition November, 2011

The tittle 'Glioma - Exploring Its Biology and Practical Relevance' is indicative of its content. This volume contains 21 chapters basically intended to explore glioma biology and discussing the experimental model systems for the purpose. It is hoped that the present volume will provide supportive and relevant awareness and understanding on the fundamental advances of the subject to the professionals from any sphere interested about glioma.

\title{
How to reference
}

In order to correctly reference this scholarly work, feel free to copy and paste the following:

Vladimir A. Kulchitsky, Michael V. Talabaev, Alexander N. Chernov, Dmitry G. Grigoriev, Yuri E. Demidchik, Dmitry G. Shcharbin, Nicholas M. Chekan, Vladimir V.Kazbanov, Tatiana A. Gurinovich, Anatoly I. Gordienko Elena K. Sergeeva, Vladimir I. Potkin and Vladimir N. Kalunov (2011). Improving the Efficiency of Chemotherapeutic Drugs by the Action on Neuroepithelial Tumors, Glioma - Exploring Its Biology and Practical Relevance, Dr. Anirban Ghosh (Ed.), ISBN: 978-953-307-379-8, InTech, Available from: http://www.intechopen.com/books/glioma-exploring-its-biology-and-practical-relevance/improving-theefficiency-of-chemotherapeutic-drugs-by-the-action-on-neuroepithelial-tumors

\section{INTECH}

open science | open minds

\section{InTech Europe}

University Campus STeP Ri

Slavka Krautzeka 83/A

51000 Rijeka, Croatia

Phone: +385 (51) 770447

Fax: +385 (51) 686166

www.intechopen.com

\section{InTech China}

Unit 405, Office Block, Hotel Equatorial Shanghai

No.65, Yan An Road (West), Shanghai, 200040, China

中国上海市延安西路65号上海国际贵都大饭店办公楼 405 单元

Phone: +86-21-62489820

Fax: +86-21-62489821 
(C) 2011 The Author(s). Licensee IntechOpen. This is an open access article distributed under the terms of the Creative Commons Attribution 3.0 License, which permits unrestricted use, distribution, and reproduction in any medium, provided the original work is properly cited. 